\title{
Temperature, energy acquisition and energy use in the Chilean silverside Basilichthys australis Eigenmann (Atherinopsidae)
}

\author{
Temperatura, adquisición de energía y uso de energía en el pejerrey chileno \\ Basilichthys australis Eigenmann (Atherinopsidae)
}

\author{
LEOPOLDO FUENTES ${ }^{1, *}$, IRMA VILA $^{2}$ \\ \& MANUEL CONTRERAS ${ }^{1,2}$
}

\author{
${ }^{1}$ Centro de Ecología Aplicada Limitada, Avenida Suecia 3304 Ñuñoa, Santiago, Chile \\ ${ }^{2}$ Departamento de Ciencias Ecológicas, Facultad de Ciencias, Universidad de Chile, Casilla 653, Santiago, Chile \\ *E-mail for corresponding author: 1fb@cea.cl
}

\begin{abstract}
We evaluated the influence of water temperature (Tw) on the energy acquisition and use in the chilean silverside Basilichthys australis (Eigenmann 1927), an endemic species inhabiting freshwater ecosystems in Chile. We tested the effect of Tw $\left(11.5,14.0,18.0,22.0\right.$ and $\left.26.0{ }^{\circ} \mathrm{C}\right)$ on food intake, digestibility, food transit time and metabolic rate. As expected, this study demonstrated that many physiological variables under study were significantly affected by $\mathrm{Tw}$, as well as the net energy balance of this species. Nevertheless, the net energy balance was not strictly related to the range of Tws evaluated. At Tws lower than $14{ }^{\circ} \mathrm{C}$ the energy budget was depressed, because food intake was lower than at Tws between 14 and 26 ${ }^{\circ} \mathrm{C}$, where food intake was higher and independent of Tw. Consequently, at these temperatures the energy balance was positive and also independent of Tw. Physiologically, B. australis appears to be a tolerant species with respect to the wide range of water temperature in habitats at different depths. Thus, its distributions may extend through the entire profile of lakes and rivers, even in systems characterised by spatial and temporal thermal variability.
\end{abstract}

Key words: water temperature, metabolic rate, food consumption, digestion, energy budget, Basilichthys australis.

\section{RESUMEN}

En este trabajo evaluamos la influencia de la temperatura del agua (Ta) en la adquisición de energía y su uso por parte del pejerrey chileno Basilichthys australis (Eigenmann 1927), una especie endémica que habita los ecosistemas dulceacuícolas de Chile. Investigamos el efecto de Ta $\left(11,5,14,0,18,0,22,0\right.$ y $\left.26,0{ }^{\circ} \mathrm{C}\right)$ en la ingesta de alimento, digestibilidad, tiempo de tránsito del alimento y tasa metabólica. De acuerdo a lo esperado, este estudio demostró que varias de las variables fisiológicas bajo estudio fueron significativamente afectadas por Ta, así como el balance energético de esta especie. Sin embargo, el balance neto de energía no estuvo estrictamente relacionado al rango de Tas evaluadas. En Tas inferiores a $14{ }^{\circ} \mathrm{C}$ el presupuesto de energía fue deprimido, debido a que la ingesta de alimento fue inferior que en Tas entre 14 y $26^{\circ} \mathrm{C}$, donde la ingesta de alimento fue mayor e independiente de Ta. Consecuentemente, en estas temperaturas el balance de energía fue positivo y también independiente de Ta. Fisiológicamente, $B$. australis parece ser una especie tolerante en un amplio rango de temperaturas acuáticas en hábitats de diferentes profundidades. Así, su distribución puede extenderse a través del entero perfil vertical de lagos y ríos, aun en sistemas caracterizados por presentar variabilidad termal en las escalas espacial y temporal.

Palabras clave: temperatura del agua, tasa metabólica, consumo de alimento, digestión, presupuesto de energía, Basilichthys australis.

\section{INTRODUCTION}

The study of energetics and thermoregulation has the potential of providing a bridge between the physiological processes taking place within an or- ganism and its ecological relationships (Soto \& Bozinovic 1998). Multiple environmental factors affect the bioenergetic of the organisms by limiting both their distributions and abundance (Hall et al. 1992), being temperature one of the most 
important abiotic factors (Johnston \& Bennett 1996). Environmental temperature varies at different time-scales, thus, organisms are continually challenged to maintain their thermoregulatory homeostasis. In order to thermoregulate, ectotherms require environmental thermal heterogeneity in time and space. As postulated by Tracy \& Christian (1986), since space and time are ecological resources, they provide the units whereby the thermal environment can be quantify as a resource. In addition, because, temperature is closely tied to the energy acquisition and use of fishes (Crowder \& Magnuson 1983), both the distributions and abundance of ectotherms might be limited by their capabilities to maintain a net energy balance in an heterothermal environment.

In fishes, studies dealing with cost-benefit of temperature and food resource use (e.g., Brett et al. 1969, Brett 1971, Shelbourn et al. 1973, Elliot 1975, 1976, Brett \& Groves 1979, Gerking \& Lee 1983, Railsback \& Rose 1999) have demonstrated a significant effect of water temperature on the net energy budget. Nevertheless, some authors (Brett \& Higgs 1970, Gerking \& Lee 1983, Cossins \& Bowler 1987) pointed out that in some fish species, not all of the physiological variables (e.g., ingestion rate, metabolic rate and digestibility) associated to the fishes net energy budget, are related to water temperature ( $\mathrm{Tw})$. We evaluated the influence of Tw on the energy acquisition (food intake, digestibility, and digesta transit time) and energy use (standard metabolic rate) of the chilean silverside Basilichthys australis (Eigenmann 1927) (Atherinopsidae), a species inhabiting freshwater ecosystems in Chile. Basilichthys australisis is omnivorous, pelagic, and inhabit the lakes and rivers from $33^{\circ} \mathrm{S}$ to $42^{\circ} \mathrm{S}$ (Arratia 1981, Campos 1973, Duarte et al. 1971, Vila et al. 1999). Water temperature along the geographic range of $B$. australis varies from 10 to $25^{\circ} \mathrm{C}$ (Fuentes 1995).

\section{MATERIAL AND METHODS}

Animals ( $\mathrm{n}=224$ individuals $)$ with a mean body mass of $20.19 \pm 0.87 \mathrm{~g}$ were captured by electrofishing (Coffelt equipment) in a stream of central Chile $\left(33^{\circ} 32^{\prime} \mathrm{S}, 70^{\circ} 51^{\prime} \mathrm{W}\right)$ and transported to the laboratory within the first two hours after capture. Fish were maintained during two weeks in the laboratory at Tw $18 \pm$
$1{ }^{\circ} \mathrm{C}$, with a photoperiod of $\mathrm{LD}=12: 12$ and with commercial fish pellet ad libitum (one pellet $=6.10 \pm 0.77 \mathrm{mg}$-dry matter $)$. We tested the long time (two weeks) effect of Tw (11.5, $14.0,18.0,22.0$ and $26^{\circ} \mathrm{C}$ ) on food intake, digestibility, food transit time and metabolic rate, in a $4 \mathrm{~L}$ thermoregulated aquarium. Energy content of food was determined in a computerised calorimeter (Parr 1261), and was $5.24 \pm 0.002 \mathrm{cal} \mathrm{mg}^{-1}$.

During the second week of treatment, we conducted feeding trials for five days offering ad lib amounts of our experimental food to each animal, and collecting faeces and remained uneaten food. The apparent digestibility was calculated as [(Qi - Qe) x $\left.\mathrm{Qi}^{-1}\right]$ x $100 \%$, where $\mathrm{Qi}=$ daily rate of food intake and $\mathrm{Qe}=$ daily rate of faeces production. Digestibility is apparent because this method underestimates digestive efficiency by the contribution of metabolic wastes and nonreabsorbed secretions of the digestive system. Apparent digestibility was calculated for dry matter, Qi was calculated as $(\mathrm{O}$ - L) x $6.10 \mathrm{mg}$-dry matter, where $\mathrm{O}=$ number of pellets offered, and $\mathrm{L}=$ number of pellets uneaten. To transform Qi to energy units, Qi was multiplied by the energy content of food (5.24 cal $\left.\mathrm{mg}^{-1}\right)$. Each day faeces were collected and Qe determined. Faeces were stored and weighed after drying up at $50{ }^{\circ} \mathrm{C}$ until constant weight. Digesta transit time was calculated as the time of first faeces production after ingestion in animals deprived of food during 2 days.

Oxygen consumption was measured at different Tws in a closed $3.9 \mathrm{~L}$ metabolic chamber connected to a Srathkelvin (model 781) oxygenometer and to a Servogor (model SE 120) recorder. Fish were placed individually in chambers with a closed flow maintained by a pump, thus the water in the chamber was mixed and the electrode was measuring a mixed sample representative of the oxygen tension in the whole chamber. Individual oxygen consumption was measured after $30 \mathrm{~min}$ of acclimation to $100 \%$ oxygen saturation and the corresponding Tw. We avoided an oxygen reduction to critical levels (70 \%). Oxygen solubility (Wetzel 2001) was considered in the determination of oxygen consumption. To transform oxygen consumption to energy units, we used $4.63 \mathrm{cal} \mathrm{L}^{-1} \mathrm{O}_{2}$ (Brett \& Groves 1979).

We excluded some fishes that did acclimate to experimental conditions. 
Based on our physiological measurements of food ingestion, digestibility, and energy expenditure, an energy balance for representative fishes of 5 and $40 \mathrm{~g}$ was conducted at each Tw. Fishes within this range of weight represent the mayor part $(96.9 \%)$ of collected fishes in the stream of origin (Fig. 1). The input of energy was calculated as Qi $x$ Digestibility, and the output of energy was equivalent to standard metabolism.

Statistical comparisons were made with the non-parametric Kruskal-Wallis test (Siegel \& Castellan 1988). On the other hand, when variables were dependent of body mass we utilised an ANCOVA test (Sokal \& Rohlf 1995). Results are reported as mean \pm 2 SE, $n=$ number of individuals.

\section{RESULTS}

Body mass of the studied individuals ranged from 5.0 to $95.0 \mathrm{~g}$. In the Chilean silverside only food intake and metabolic rate were dependent on body mass. Linear models adjusted to both variables as a function of Tw are shown in Table 1. Calculated values of standard metabolism and intake of food for fishes of 5 and 40 $\mathrm{g}$ are in Table 2, and graphically linear models for fishes between 5 and $40 \mathrm{~g}$ are in Fig. 2 and Fig. 3. Slope analysis of double logarithmic models for data of metabolic rate versus body mass, revealed that slopes were not significantly different among different temperatures (ANCOVA, $\mathrm{F}_{4,195}=0.504, \mathrm{P}=0.733$ ). Because we observed statistical homogeneity in slopes, an average slope was calculated, being $0.781 \pm$ 0.199 for the relationship between metabolic rate and body mass. Intercepts however, were significantly different (ANCOVA, $\mathrm{F}_{4,199}=$ $15.731, \mathrm{P}=0.0001)$. A significant correlation was observed between intercepts and Tw (Pearson correlation coefficient: $\mathrm{r}=0.385 ; \mathrm{n}=205$; $\mathrm{P}=0.0001)$, indicating that the metabolic rate of the Chilean silverside increases with Tw. A similar pattern was observed for the relationships between food intake and body mass at different Tw, with slopes homogeneity (ANCO$\left.\mathrm{VA}, \mathrm{F}_{4,196}=1.660, \mathrm{P}=0.163\right)$, being an average of $0.930 \pm 0.379$. Nevertheless, intercepts were significantly different (ANCOVA, $\left.\mathrm{F}_{4,150}=14.141, \mathrm{P}=0.0001\right)$. A significant positive correlation was observed between maximum food intake and Tw (Pearson correlation coefficient: $\mathrm{r}=0.335, \mathrm{n}=156, \mathrm{P}=0.0001)$. The a-posteriori Tukey test indicated, however that at only $11.5{ }^{\circ} \mathrm{C}$ intake was significantly lower than that at the other tested Tws.

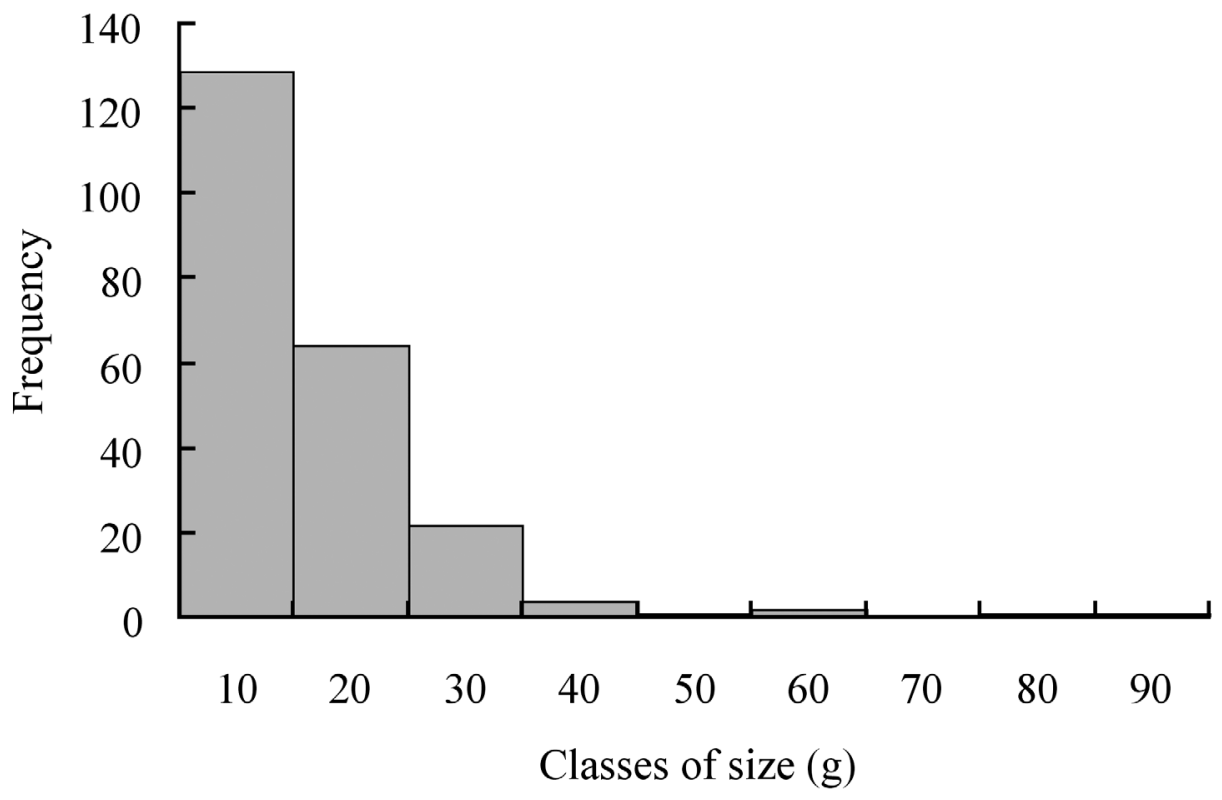

Fig. 1: Frequency distribution of corporal size (body weight in grams) in experimental individuals of Basilichthys australis in this study.

Distribución de frecuencia de los tamaños corporales (peso corporal en gramos) en los individuos experimentales de Basilichthys australis en este estudio. 


\section{TABLE 1}

Double logarithmic linear regressions among (A) standard metabolism and (B) food intake as a function of individual body mass at different water temperatures

Regresiones lineales doble logarítmicas entre el (A) metabolismo estándar y (B) la ingesta de alimento como función de la masa corporal en diferentes temperaturas del agua

(A) Metabolic rate $\left(\mathrm{mg} \mathrm{O}_{2} \mathrm{~h}^{-1}\right)$ versus body mass ( $\mathrm{g}$ )

\begin{tabular}{lcccccr} 
Treatment & Regression & $\mathrm{n}$ & r-value & df & t-value & P-value \\
\hline $11.5{ }^{\circ} \mathrm{C}$ & $\log \mathrm{Y}=-0.380+0.698 \log \mathrm{X}$ & 32 & 0.748 & 30 & 6.168 & $<0.0001$ \\
$14{ }^{\circ} \mathrm{C}$ & $\log \mathrm{Y}=-0.461+0.693 \log \mathrm{X}$ & 43 & 0.813 & 41 & 8.926 & $<0.0001$ \\
$18{ }^{\circ} \mathrm{C}$ & $\log \mathrm{Y}=-0.435+0.788 \log \mathrm{X}$ & 44 & 0.808 & 42 & 8.874 & $<0.0001$ \\
$22{ }^{\circ} \mathrm{C}$ & $\log \mathrm{Y}=-0.416+0.842 \log \mathrm{X}$ & 45 & 0.846 & 43 & 10.417 & $<0.0001$ \\
$26{ }^{\circ} \mathrm{C}$ & $\log \mathrm{Y}=-0.373+0.768 \log \mathrm{X}$ & 41 & 0.693 & 39 & 6.010 & $<0.0001$
\end{tabular}

(B) Intake (pellet day ${ }^{-1}$ ) versus body mass $(\mathrm{g})$

\begin{tabular}{lcccccr} 
Treatment & Regression & $\mathrm{n}$ & r-value & df & t-value & P-value \\
\hline $11.5{ }^{\circ} \mathrm{C}$ & $\mathrm{Y}=6.877+0.557 \mathrm{X}$ & 19 & 0.774 & 17 & 5.038 & 0.0001 \\
$14{ }^{\circ} \mathrm{C}$ & $\mathrm{Y}=12.291+1.002 \mathrm{X}$ & 36 & 0.785 & 34 & 7.339 & $<0.0001$ \\
$18{ }^{\circ} \mathrm{C}$ & $\mathrm{Y}=13.300+1.093 \mathrm{X}$ & 38 & 0.663 & 36 & 5.312 & $<0.0001$ \\
$22{ }^{\circ} \mathrm{C}$ & $\mathrm{Y}=13.857+0.955 \mathrm{X}$ & 35 & 0.673 & 33 & 5.221 & $<0.0001$ \\
$26{ }^{\circ} \mathrm{C}$ & $\mathrm{Y}=21.250+0.672 \mathrm{X}$ & 28 & 0.440 & 26 & 2.502 & 0.019 \\
\hline
\end{tabular}

TABLE 2

Predicted (A) standard metabolic rate and (B) food intake ( \pm SE) for a 5 and $40 \mathrm{~g}$ fish (A) Tasa metabólica estándar e (B) ingesta de alimento predichas $( \pm \mathrm{EE})$ para peces de 5 y $40 \mathrm{~g}$

(A) Metabolic rate $\left(\mathrm{mg} \mathrm{O}_{2} \mathrm{~h}^{-1}\right)$

Body mass $(\mathrm{g})$

Temperature $\left({ }^{\circ} \mathrm{C}\right)$

\begin{tabular}{cccccc} 
& 11.5 & 14 & 18 & 22 & 26 \\
\hline 5 & 1.282 & 1.056 & 1.305 & 1.485 & 1.459 \\
& \pm 1.188 & \pm 1.123 & \pm 1.129 & \pm 1.093 & \pm 1.187 \\
40 & 5.475 & 4.460 & 6.716 & 8.553 & 7.207 \\
& \pm 1.102 & \pm 1.073 & \pm 1.094 & \pm 1.110 & \pm 1.123
\end{tabular}

(B) Intake (pellet day $\left.{ }^{-1}\right)$

Body mass (g)

Temperature $\left({ }^{\circ} \mathrm{C}\right)$

\begin{tabular}{cccccc} 
& 11.5 & 14 & 18 & 22 & 26 \\
\hline 5 & 9.662 & 17.301 & 18.765 & 18.632 & 24.610 \\
& \pm 2.401 & \pm 2.760 & \pm 2.998 & \pm 2.300 & \pm 3.461 \\
40 & 29.157 & 52.371 & 57.02 & 52.057 & 48.130 \\
& \pm 2.374 & \pm 2.924 & \pm 4.865 & \pm 5.132 & \pm 6.528 \\
\hline
\end{tabular}




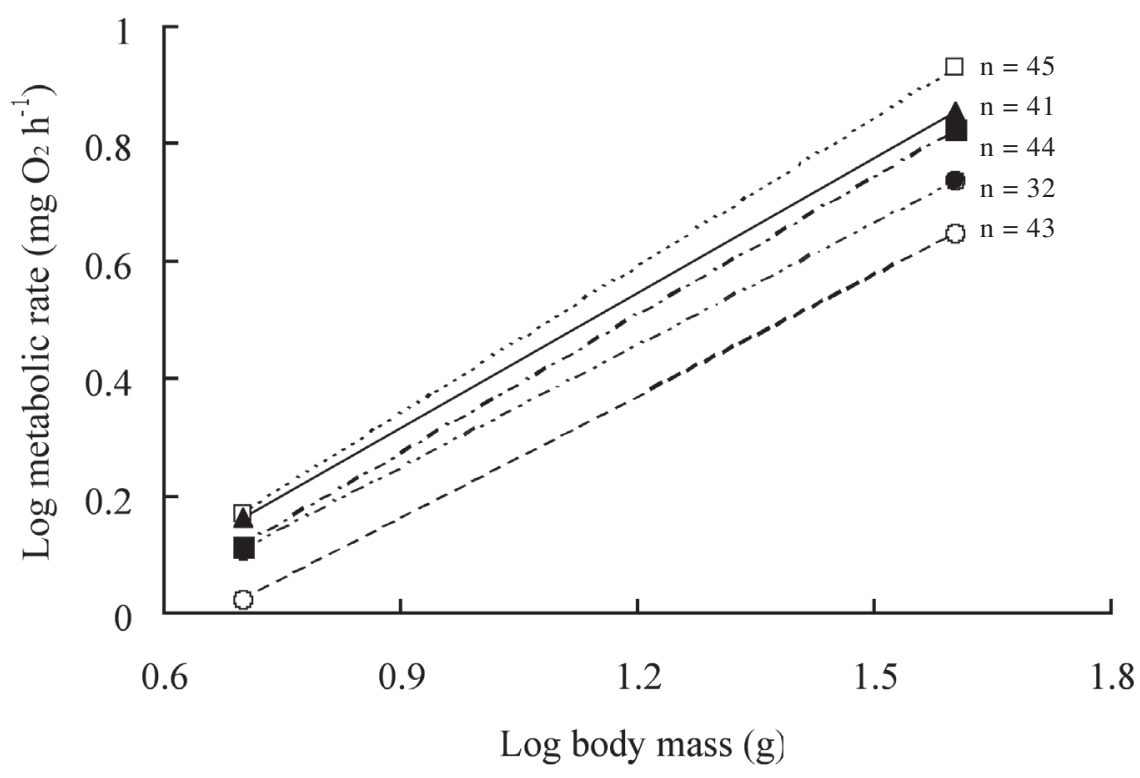

$-\cdots 11.5^{\circ} \mathrm{C} \quad-\mathrm{O}^{\circ}-14^{\circ} \mathrm{C} \quad--18^{\circ} \mathrm{C} \quad \cdots \square \cdot 22^{\circ} \mathrm{C} \quad \longleftarrow 26^{\circ} \mathrm{C}$

Fig. 2: Standard metabolism as a function of body mass and water temperature in Basilichthys australis. Double logarithmic models are graphicated for fish between 5 and $40 \mathrm{~g}$ of body mass.

Metabolismo estándar como función de la masa corporal y la temperatura del agua en Basilichthys australis. Los modelos doble logarítmicos son graficados para peces entre 5 y $40 \mathrm{~g}$ de masa corporal.

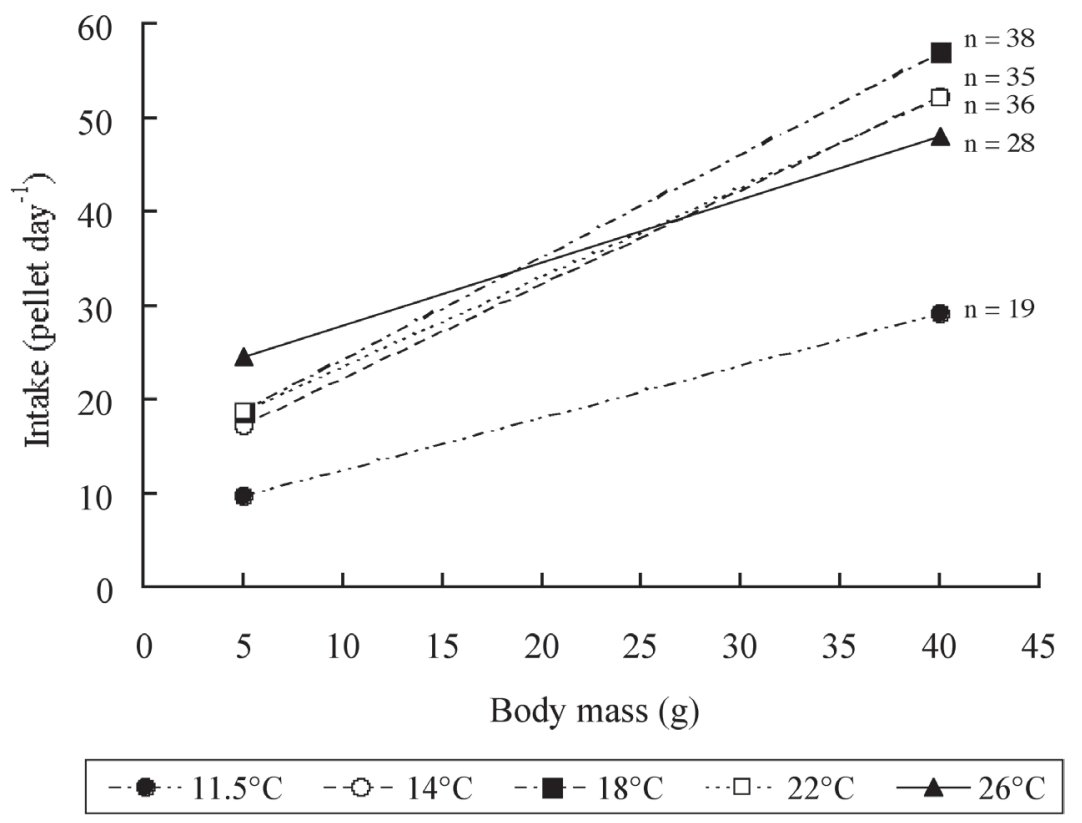

Fig. 3: Food intake as a function of body mass and water temperature in Basilichthys australis. The linear models are graphicated for fish between 5 and $40 \mathrm{~g}$ of body mass.

Ingesta de alimento como función de la masa corporal y la temperatura del agua en Basilichthys australis. Los modelos lineales son graficados para peces entre 5 y $40 \mathrm{~g}$ de masa corporal. 
On the other hand, Tw affects significatively both digestibility (KruskalWallis test, $\left.\mathrm{H}_{4,168}=80.118, \mathrm{P}<0.0001\right)$ and digesta transit time (Kruskal-Wallis test, $\left.\mathrm{H}_{4,156}=96.757, \mathrm{P}<0.0001\right)$. Furthermore, both variables were also correlated with Tw (apparent digestibility: $\mathrm{r}_{\mathrm{S}}=0.680, \mathrm{n}=168, \mathrm{P}$ $=0.0001$; Fig. 4 ; and digesta transit time: $\mathrm{r}_{\mathrm{S}}=$ $-0.783, \mathrm{n}=156, \mathrm{P}=0.00001$; Fig. 5). Finally, The net energy balance for small and larger individuals (Fig. 6A y 6B) was independent of Tw between 14 and $26^{\circ} \mathrm{C}$. In fact, only at 11.5 ${ }^{\circ} \mathrm{C}$ energy input was depressed in comparison to energy output, mainly in smaller individuals.

\section{DISCUSSION}

This study, the first one conducted in an endemic freshwater Chilean fish, demonstrated that, as expected, many physiological variables under study were significantly affected by Tw, as well as net energy balance. However, the net energy balance in this species was not strictly related to the evaluated range of Tw. At Tw lower than $14{ }^{\circ} \mathrm{C}$ the energy budget was depressed, because food intake was lower than at Tws between 14 and $26{ }^{\circ} \mathrm{C}$, where food intake was higher and independent of Tw. Consequently, at these Tws the energy balance was positive and also independent of Tw. On the other hand, both the metabolic rate and apparent digestibility increased with Tw. Obtained values of $\mathrm{Q}_{10}$ were 1.32 for metabolic rate and 1.08 for apparent digestibility, explaining the parallelism between energy input and output at Tws ranging between 14 and $26{ }^{\circ} \mathrm{C}$. Up to date, observed values of $\mathrm{Q}_{10}$ are some of the lower values reported for fishes. In fact reported $\mathrm{Q}_{10}$ values in different fish species ranged from 1.66 to 2.81 (Brett 1964, Dickson \& Kramer 1971, Brett \& Groves 1979,Cossins \& Bowler 1987). Our observed $\mathrm{Q}_{10}$ value for apparent digestibility, however, was similar to the one reported by Elliot (1976) in Salmo trutta.

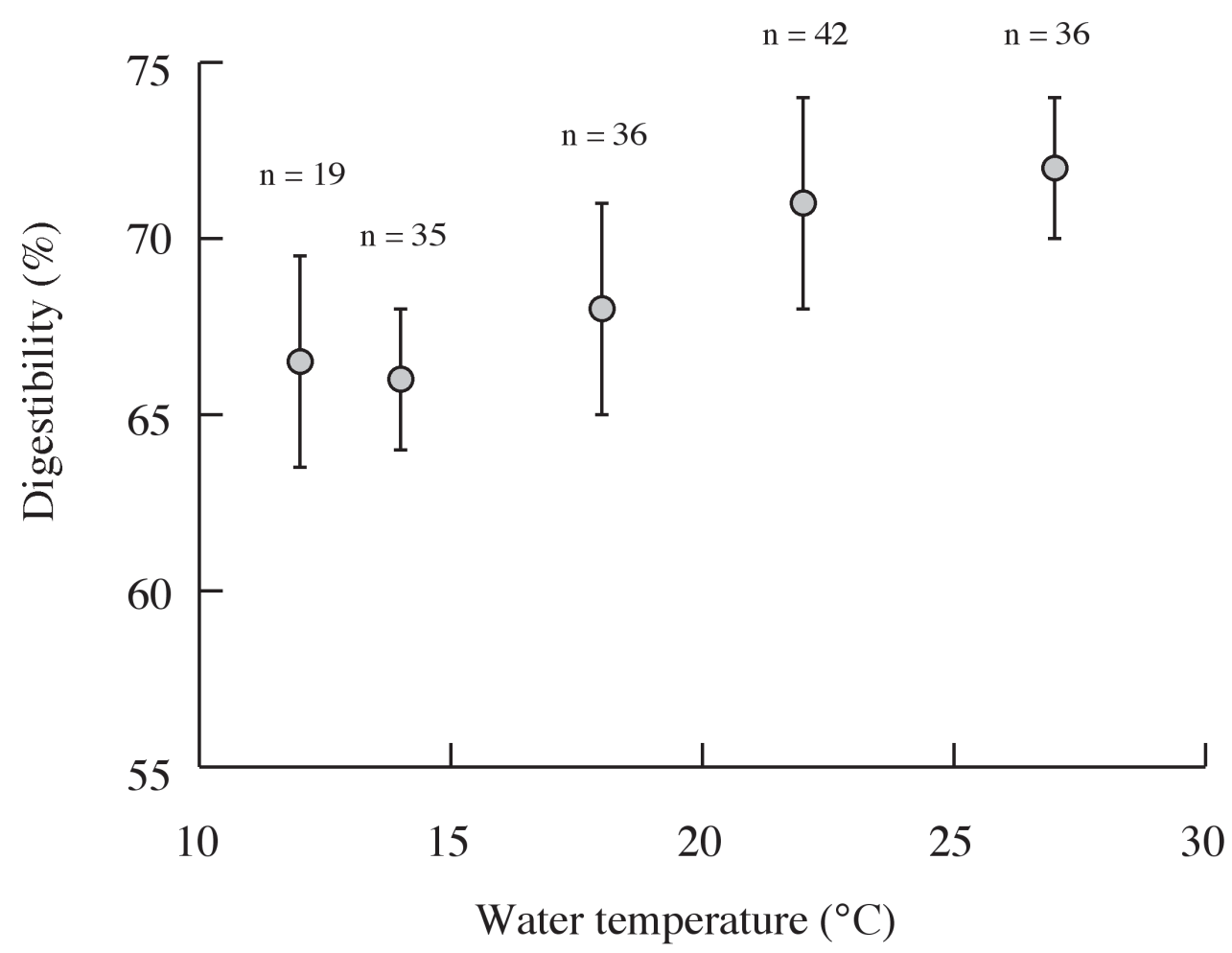

Fig. 4: Food digestibility as a function of water temperature in Basilichthys australis. Each point represents the median of data and the associated range at each temperature.

Digestibilidad de alimento como función de la temperatura del agua en Basilichthys australis. Cada punto representa la mediana de los datos y el rango asociado a cada temperatura. 


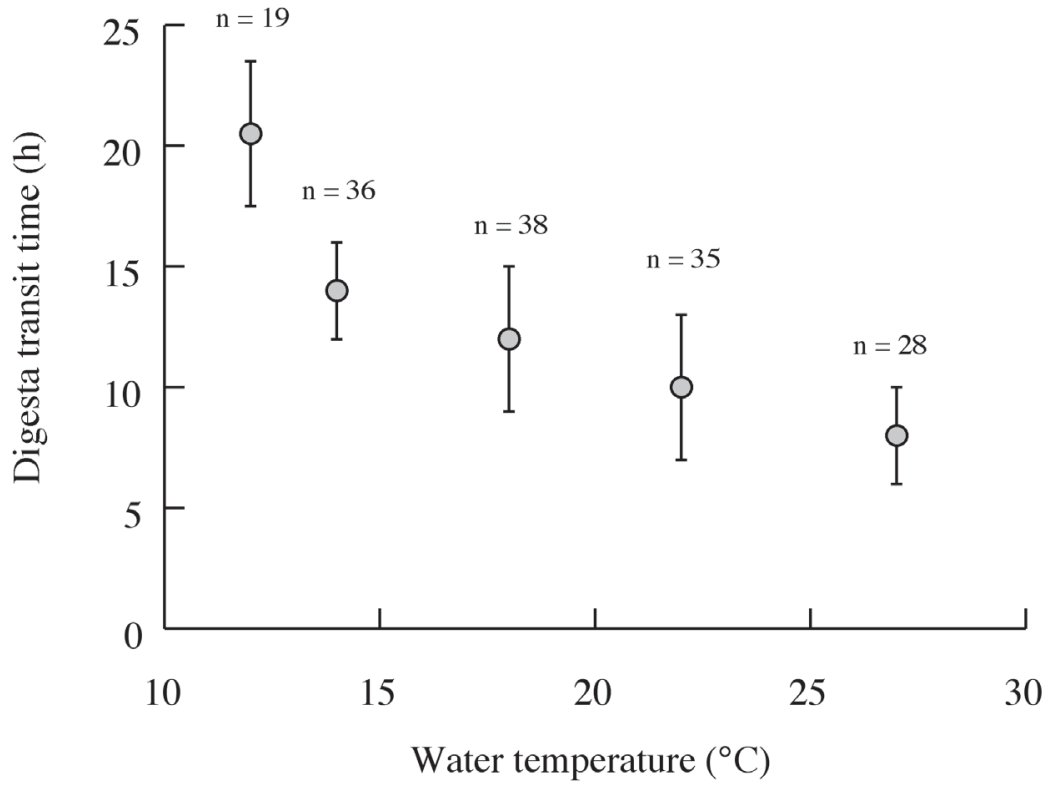

Fig. 5: Digesta transit time as a function of water temperature in Basilichthys australis. Each point represents the median of data and the associated range at each temperature.

Tiempo de tránsito del alimento como función de la temperatura del agua en Basilichthys australis. Cada punto representa la mediana de los datos y el rango asociado a cada temperatura.

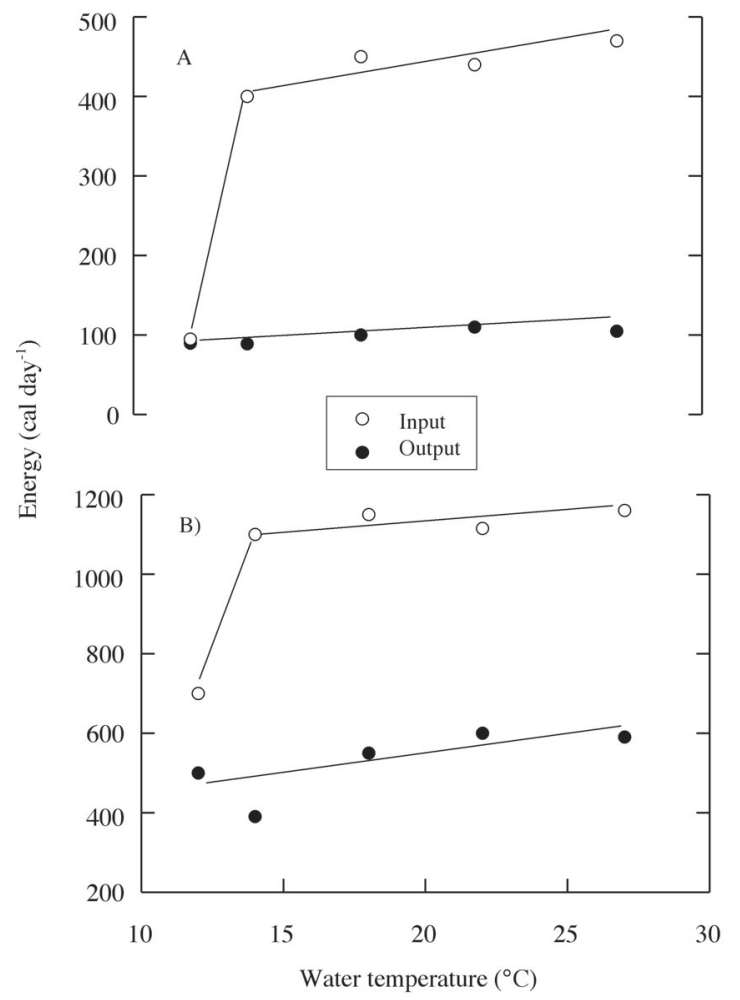

Fig. 6: Energy budget under ad libitum food availability as a function of water temperature. (A) Energy budget for individuals of Basilichthys australis of $5 \mathrm{~g}$, and (B) for individuals of $40 \mathrm{~g}$.

Presupuesto de energía en condiciones de alimentación ad libitum como función de la temperatura del agua. (A) Presupuesto de energía para individuos de Basilichthys australis de $5 \mathrm{~g}$, y (B) para individuos de $40 \mathrm{~g}$. 
Basilichthys australis is capable of maintaining a positive net energy balance in a wide range of $\mathrm{Tw}$, which may explain the large range of geographic distributions exhibited by this species. Also, this species is capable to maintain a positive energy budget despite temporal and spatial changes in Tw along its distributional range. Nevertheless below $14{ }^{\circ} \mathrm{C}$, this species, and mainly smaller individuals, are unable to maintain their net energy budget. This characteristic may explain the differential space use and patch choice of juveniles in comparison to adults, and also the temporal pattern of reproduction and abundance of adults. In fact, Duarte et al. (1971) pointed out that juveniles of $B$. australis prefer shallow water areas, patches that are more temperate than the deep water areas selected by adults in central Chilean rivers. The reproduction of this species, on the other hand, occurs in spring, when the surface water temperature varies between 13 and $21{ }^{\circ} \mathrm{C}$ (Vila \& Soto 1981).

Some characteristics of natural food for fish, like prey size, form and humidity level, as well as some characteristics of predator fish, like its ontogenetic level of development or corporal size, can modify the digestive processes ((Knusten \& Salvanes 1999) in relation to responses gotten from feeding with little size deshidrated commercial pellet. In the particular case of $B$. australis these changes would be meaningless because its diet is mainly constituted by insect larvae and small invertebrate, items with low hydric contents (Duarte et al. 1971, Bahamondes et al. 1979), a behavior also observed in the case of $B$. australis of large body size (Bahamondes et al. 1979).

In general and physiologically, the Chilean silverside appears to be a tolerant species with respect to the wide range of water temperature in habitats at different depth levels. Thus, its distribution may extend the entire depth of lakes and rivers, even in ecosystems characterised by spatial and temporal thermal variability (Contreras 1992). In spite of a wide range of $\mathrm{Tw}$, this may not significantly affect the net energy balance in B. australis. Finally, simultaneous environmental factors such as food abundance, water movement, and predation risk need to be considered and tested as factors that, in addition to fish energetic, may operate affecting the costs and benefits of foraging, and the abundance and distribution of this species (Crowder \& Magnuson 1983, Werner et al. 1983, Werner \& Gilliam 1984, Contreras 1992, Hill \& Grossman 1993, Welsh et al. 2001). Certainly, the generality of our findings needs to be tested in other species inhabiting different freshwater geographic areas in Chile to determine whether our conclusions apply to other systems.

\section{ACKNOWLEDGMENTS}

This work was partially funded by a Fondo Nacional de Desarrollo Científico y Tecnológico FONDECYT 1980959 grant to F. Bozinovic. Patricio A. Camus, F. F. Novoa and an anonymous corrector provided useful comments on the manuscript.

\section{LITERATURE CITED}

ARRATIA G (1981) Géneros de peces de aguas continentales de Chile. Museo Nacional de Historia Natural, Publicación Ocasional 34: 1-108.

BAHAMONDES L, D Soto \& I Vila (1979) Hábitos alimentarios de los pejerreyes (Pisces Atherinidae) del embalse Rapel Chile. Medio Ambiente (Chile) 4: 3-18.

BRETT JR (1964) The respiratory metabolism and swimming performance of young sockeye salmon. Journal of the Fisheries Research Board of Canada. 21: 1183-226.

BRETT JR (1971) Energetic responses of salmon to temperature. A study of same thermal relations in the physiology and freshwater ecology of sockeye salmon (Oncorhynchus nerka). American Zoologist 11: 99-113.

BRETT JR, JE SHELBOURN \& CT SHOOP (1969) Growth rate and body composition of fingerling sockeye salmon, Oncorhynchus nerka, in relation to temperature and ration size. Journal of the Fisheries Research Board of Canada 26: 2363-2394.

BRETT JR \& DA HIGGS (1970) Effect of temperature on the rate of gastric digestion in fingerling sockeye salmon, Oncorhynchus nerka. Journal of the Fisheries Research Board of Canada 27: 1767-1779.

BRETT JR \& DD GROVE (1979) Physiological Energetics. In: Hoar WS, DJ Randall \& JR Brett (eds) Fish physiology, bioenergetics and growth: 279-352. Academic Press, San Diego, California, USA.

CAMPOS H (1973) Lista de peces de aguas continentales de Chile. Noticiero Mensual del Museo de Historia Natural (Chile) 14: 3-9.

CONTRERAS ML (1992) Desplazamientos diarios de Odontesthes bonariensis (Valenciennes) en el Embalse Rapel (Pices: Atherinidae). Tesis de Magíster, Universidad de Chile, Santiago, Chile. 84 pp.

COSSINS AR \& RK BOWLER (1987) Rate compensations and capacity adaptations. In: 
Cossins AR \& RK Bowler (eds) Temperature biology of animals: 155-203. Chapman \& Hall, London, United Kingdom.

CROWDER LB \& JJ MAGNUSON (1983) Cost-benefit analysis of temperature and food resource use: a synthesis with examples from fishes. In: Aspey WP \& SI Lustick (eds) Behavioural energetics: 189221. Ohio State University Press, Columbus, Ohio, USA.

DICKSON IW \& RH KRAMER (1971) Factors influencing scope for activity and active and standard metabolism of rainbow trout (Salmo gairdneri). Journal of the Fisheries Research Board of Canada 228: 587-596.

DUARTE W, R FEITO, C JARA, C MORENO \& AE ORELLANA (1971) Ictiofauna del sistema hidrográfico del río Maipo. Boletín del Museo Nacional de Historia Natural (Chile) 32: 227-268.

ELLIOT JM (1975) The growth rate of brown trout (Salmo trutta $L$.) fed on reduced rations. Journal of Animal Ecology 44: 823-842.

ELLIOT JM (1976) Energy losses in the waste products of brown trout (Salmo trutta L.). Journal of Animal Ecology 45: 561-580.

FUENTES LS (1995) Efecto de la abundancia de alimento en la energética y conducta termorregulatoria de Basilichthys australis Eigenmann 1927 (Athernidae). M.Sc. Thesis, Universidad de Chile. $60 \mathrm{pp}$.

GERKING SD \& RM LEE (1983) Thermal limits for growth and reproduction in the desert pupfish (Cyprinodon n. nevadensis). Physiological Zoology 56: 1-9.

HALL CAS, JA STANFORD \& FR HAUER (1992) The distribution and abundance of organism as a consequence of energy balances along multiple environmental gradients. Oikos 65: 377-390.

HILL J \& GD GROSSMAN (1993) An energetic model of microhabitat use for rainbow trout and rosyside dace. Ecology 74: 685-698.

JOHNSTON IA \& AF BENNETT (1996) Animals and temperature: phenotypic and evolutionary adaptation. Cambridge University Press, Cambridge, United Kingdom. 419 pp.

KNUSTSEN I \& AGV SALVANES (1999) Temperaturedependent digestion handling time in juvenile cod and possible consequences for prey choice. Marine Ecology Progress Series 181: 61-79.
RAILSBACK SE \& KA ROSE (1999) Bioenergetics modeling of stream trout growth: temperature and food consumption effects. Transactions of the American Fisheries Society 128: 241-256.

SHELBOURN JE, JR BRETT \& S SHIRAHATA (1973) Effect of temperature and feeding regime on the specific growth rate of sockeye salmon fry (Oncorhynchus nerka), with a consideration of size effect. Journal of the Fisheries Research Board of Canada 30: 1191-1194.

SIEGEL S \& NJ CASTELLAN (1988) Nonparametric statistics for the behavioural sciences. McGraw-Hill Book Company, New York, New York, USA. 395 pp.

SOKAL RR \& FJ ROHLF (1995) Biometry. Third edition. W.H. Freeman \& Co., New York, New York, USA. $887 \mathrm{pp}$.

SOTO RE \& F BOZINOVIC (1998) Behavioral thermoregulation of the periwinkle Nodilittorina peruviana inhabiting the rocky intertidal of central Chile: a laboratory and field study. Revista Chilena de Historia Natural 71: 375-382.

TRACY CR \& KA CHRISTIAN (1986) Ecological relations among space, time, and thermal niche axes. Ecology 67: 609-615.

VILA I \& D SOTO (1981) Atherinidae (Pisces) of Rapel reservoir, Chile. Verhandlungen Internationale Vereinigung Für Theoretische und Angewandte Limnolgie 21: 334-1338.

VILA I, L FUENTES \& M CONTRERAS (1999) Peces límnicos de Chile. Boletín del Museo de Historia Natural (Chile) 48: 61-75.

WELSH JR HH, GR HODGSON \& B HARVEY (2001) Distribution of juvenil Coho Salmon in relation to water temperatures in tributaries of Mattole River, California. North American Journal of Fisheries Management 21: 464-470.

WERNER EE, JF GILLIAM, DJ HALL \& GG MITTELBACH (1983) An experimental test of the effects of predation risk on habitat use in fish. Ecology 64: 1540-1548.

WERNER EE \& JF GILLIAM (1984) The ontogenetic niche and species interactions in size - structured populations. Annual Review of Ecology and Systematics 15: 393-425.

WETZEL RG (2001) Limnology: lake and river ecosystems. Third edition. Academic Press, San Diego, California, USA. 1,006 pp. 